\title{
Tropospheric ozone sources and wave activity over Mexico City and Houston during MILAGRO/Intercontinental Transport Experiment (INTEX-B) Ozonesonde Network Study, 2006 (IONS-06)
}

\author{
A. M. Thompson ${ }^{1}$, J. E. Yorks ${ }^{1}$, S. K. Miller ${ }^{1}$, J. C. Witte ${ }^{2,}{ }^{*}$, K. M. Dougherty ${ }^{1}$, G. A. Morris ${ }^{3}$, D. Baumgardner ${ }^{4}$, \\ L. Ladino ${ }^{4}$, and B. Rappenglück ${ }^{5}$ \\ ${ }^{1}$ The Pennsylvania State University, Department of Meteorology, 503 Walker Building, University Park, PA, USA \\ ${ }^{2}$ SSAI of Lanham, MD, USA \\ ${ }^{3}$ Valparaiso University, Dept. of Physics and Astronomy, Valparaiso, IN, USA \\ ${ }^{4}$ UNAM (Autonomous University of Mexico), CCA - Center for Chemistry of the Atmosphere, Mexico City, Mexico \\ ${ }^{5}$ University of Houston, Geosciences Department, Old Sciences Bldg, Houston, TX, USA \\ *also at: NASA/Goddard Space Flight Center, Greenbelt, MD, USA
}

Received: 8 January 2008 - Published in Atmos. Chem. Phys. Discuss.: 26 March 2008

Revised: 1 July 2008 - Accepted: 23 July 2008 - Published: 2 September 2008

\begin{abstract}
During the INTEX-B (Intercontinental Chemical Transport Experiment)/ MILAGRO (Megacities Initiative: Local and Global Research Observations) experiments in March 2006 and the associated IONS-06 (INTEX Ozonesonde Network Study; http://croc.gsfc.nasa. gov/intexb/ions06.html), regular ozonesonde launches were made over 15 North American sites. The soundings were strategically positioned to study inter-regional flows and meteorological interactions with a mixture of tropospheric $\mathrm{O}_{3}$ sources: local pollution; $\mathrm{O}_{3}$ associated with convection and lightning; stratosphere-troposphere exchange. The variability of tropospheric $\mathrm{O}_{3}$ over the Mexico City Basin (MCB; $\left.19^{\circ} \mathrm{N}, 99^{\circ} \mathrm{W}\right)$ and Houston $\left(30^{\circ} \mathrm{N}, 95^{\circ} \mathrm{W}\right)$ is reported here. MCB and Houston profiles displayed a double tropopause in most soundings and a subtropical tropopause layer with frequent wave disturbances, identified through $\mathrm{O}_{3}$ laminae as gravity-wave induced. Ozonesondes launched over both cities in August and September 2006 (IONS-06, Phase 3) displayed a thicker tropospheric column $\mathrm{O}_{3}(\sim 7$ DU or 15$20 \%$ ) than in March 2006; nearly all of the increase was in the free troposphere. In spring and summer, $\mathrm{O}_{3}$ laminar structure manifested mixed influences from the stratosphere, convective redistribution of $\mathrm{O}_{3}$ and precursors, and $\mathrm{O}_{3}$ from lightning NO. Stratospheric $\mathrm{O}_{3}$ origins were present in $39 \%$ (MCB) and 60\% (Houston) of the summer sondes. Compar-
\end{abstract}

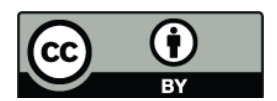

Correspondence to: A. M. Thompson (anne@meteo.psu.edu) ison of summer $2006 \mathrm{O}_{3}$ structure with summer 2004 sondes (IONS-04) over Houston showed 7\% less tropospheric $\mathrm{O}_{3}$ in 2006. This may reflect a sampling contrast, August to midSeptember 2006 instead of July-mid August 2004.

\section{Introduction}

A number of multi-national, multi-platform field experiments have been conducted to quantify intra- and intercontinental pollution transport. The 2004 ICARTT (International Consortium on Atmospheric Research on Transport and Transformation)/ INTEX (Inter-continental Transport Experiment - North America; Fehsenfeld et al., 2006; Singh et al., 2006) and 2006 MILAGRO/INTEX-B (Fast et al., 2007; Molina et al., 2008 ${ }^{1}$; Singh et al., 2008 ${ }^{2}$ ) used multiple aircraft to follow pollutant transport into and out of North America. With the launch of the Aura spacecraft carrying four sensors in 2004 (http://aura.gsfc.nasa.gov; Schoeberl et al., 2007), tropospheric $\mathrm{O}_{3}$, a major pollutant, could

\footnotetext{
${ }^{1}$ Molina, L. T., Madronich, S., Gaffney, J., et al.: An overview of the MILAGRO 2006 Campaign: Mexico City emissions and its transport and transformation, Atmos. Chem. Phys. Discuss., in preparation, 2008.

${ }^{2}$ Singh, H. B., Brune, W. H., Crawford, J. H., Jacob, D. J., et al.: Chemistry and Transport of Pollution over the Gulf of Mexico and the Pacific: Spring 2006 INTEX-B Campaign Overview and First Results, Atmos. Chem. Phys. Discuss., in preparation, 2008.
}

Published by Copernicus Publications on behalf of the European Geosciences Union. 
Table 1. IONS06 Stations. Spring refers to Phases 1 and 2 (MILAGRO/INTEX-B), March-mid-May. Summer is Phase 3 (August-midSeptember).

\begin{tabular}{llll}
\hline Station & Lat, Lon & Spring period (SN) & Summer period (SN) \\
\hline Barbados & $13.2,-59.5$ & - & 19 Jul-30 Aug (27) \\
Beltsville, MD* & $39.0,-76.5$ & - & 1-28 Aug (12) \\
Boulder, CO* & $40.3,-105.2$ & 28 Mar-18 May (9) & 14 Jul-31 Aug (34) \\
Bratt's Lake, SAS & $50.2,-104.7$ & 3 Mar-17 May (32) & 1-30 Aug (29) \\
Egbert, ONT* & $44.2,-79.8$ & 8 Mar-17 May (8) & 1-30 Aug (15) \\
Holtville, CA & $32.8,-115.4$ & - & 7-31 Aug (13) \\
Houston, TX* & $29.7,-95.4$ & 1 Mar-10 May (21) & 1-31 Aug (19) \\
Huntsville, AL* & $35.3,-86.6$ & 1 Mar-9 May (14) & 1 Aug-2 Sep (30) \\
Kelowna, BC & $49.9,-119.4$ & 8 Mar-17 May (28) & 2-30 Aug (27) \\
Narragansett, RI* & $41.5,-71.4$ & 8 Mar-12 May (14) & 18 Jul-30 Aug (30) \\
Paradox, NY & $43.9,-73.6$ & - & 30 Jun-30 Aug (8) \\
Richland, WA & $46.0,-119.0$ & 21 Apr-15 May (24) & - \\
R/V Ronald H Brown & Gulf of Mex. & - & 31 Jul-11 Sep (35) \\
Sable Is, NS* & $44.0,-60.0$ & - & 1-31 Aug (28) \\
Socorro, NM & $36.4,-106.9$ & - & 1 Aug-9 Sep (26) \\
Stonyplain, ALB & $53.6,-114.1$ & 8 Mar-18 May (7) & 9 Aug-30 Aug (4) \\
Trinidad Head, CA* & $40.8,-124.2$ & 3 Mar-19 May (21) & 27 Jul-31 Aug (31) \\
Table Mtn, CA & $34.4,-117.7$ & 10-26 Apr (6) & 1-31 Aug (30) \\
Mexico City ** & $19.4,-98.6$ & 7-20 Mar (13) & 22 Aug-20 Sep (22) \\
Valparaiso, IN & $41.5,-87.0$ & 19 Apr-16 May (15) & 2-31 Aug (5) \\
Wallops Is, VA* & $37.9,-75.5$ & 1 Mar-17 (12) & 2-30 Aug (11) \\
Walsingham, ON & $42.6,-80.6$ & 24 Apr-5 May (21) & 14-25 Aug (22) \\
Yarmouth, NS* & $43.9,-66.1$ & 8 Mar-16 May (8) & 2-30 Aug (13) \\
\hline & & &
\end{tabular}

* Also participated in IONS-04 (Thompson et al., 2007a, b).

** Mexico City: Tecamac (State of Mexico) in Spring (MILAGRO T1 Site); at UNAM (Autonomous University of Mexico, Federal District) in Summer.

be measured with some of its precursors (Zhang et al., 2006), providing a larger view of pollution transport. Although surface monitoring for pollutants like $\mathrm{O}_{3}, \mathrm{CO}$ and aerosol, is useful, trans-boundary and intercontinental transport often take place in the free troposphere (FT), just above the mixed layer $(1-3 \mathrm{~km})$ or in the mid-troposphere. The midtroposphere is also subject to direct injection of pollutants from convection, introduction of NO from lightning (Pickering et al., 1992; Ridley et al. 1996; Huntrieser et al., 2002) and stratospheric $\mathrm{O}_{3}$, frequently leading to thin layers and transport over long distances (Newell et al., 1999; Oltmans et al., 2004).

Neither satellite nor aircraft instruments resolve pollutant structure from surface through the lower stratosphere, something that combined ozonesonde-radiosonde packages from balloons offer for $\mathrm{O}_{3}$. Thus, strategically designed sounding networks are an integral part of field campaigns. IONS-06 (INTEX Ozonesonde Network Study) operating during MILAGRO/INTEX-B (Phase 1=March 2006; Phase 2=mid-April-mid-May 2006; Phase 3=Augustmid-September 2006), supplied $>700 \mathrm{O}_{3}$ and pressuretemperature-humidity (PTU) profile sets from surface to $\sim 35 \mathrm{~km}(5 \mathrm{hPa})$ at 23 North American stations (Table 1, cir- cles in Fig. 1). The IONS-06 soundings provided profiles for Aura instrument validation (e.g. Jiang et al., 2007; Schoeberl et al., 2007), for integrating field measurements and for evaluation of models (e.g. Pierce et al., 2007; Parrington et al., 2007).

The IONS-06 sonde network built on a similar effort, IONS-04, during the INTEX-A campaign; refer to the special INTEX-A/ICARTT (Singh et al., 2006; Fehsenfeld et al., 2006). IONS-04 was initiated to complement North American aircraft sampling and satellite measurements of $\mathrm{O}_{3}$, temperature and humidity (Thompson et al., 2007a, b), with eleven sites and sonde launches timed for Aura overpasses. IONS-04 configured sampling from the south central US through New England and the maritimes (Fig. 1, solid dots) to encompass major pollution sources and the route of eastward export from North America (* symbol in Table 1 gives IONS-04 station coordinates). Combining forecasts with near-real-time $\mathrm{O}_{3}$ data permitted INTEX-A and ICARTT aircraft to target sampling over North America, the Atlantic and Europe. 
IONS-04/IONS-06 Locations

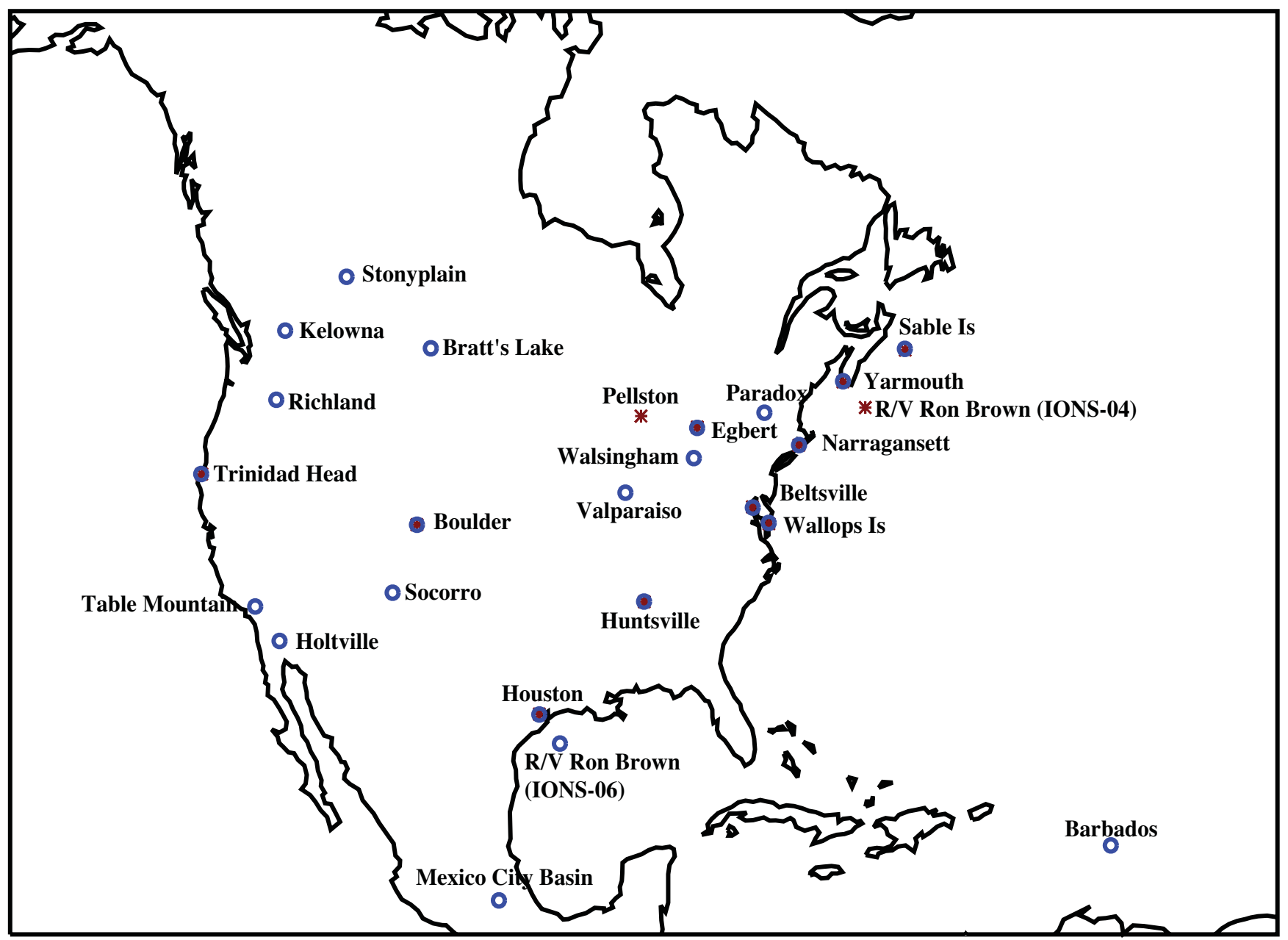

Fig. 1. Map of IONS-04 (solid and starred) sites with the additional sites that comprised IONS-06 (open circles). See Table 1 for coordinates. The R/V Ronald H Brown ship operated in the Gulf of Maine in IONS-04 and in the Gulf of Mexico in Phase 3 of IONS-06 (AugustSeptember 2006).

Unexpected findings in IONS-04 were:

1. the prevalence of high- $\mathrm{O}_{3}$ concentrations in the middle and upper troposphere (UT; Cooper et al., 2006; Thompson et al., 2007a) and

2. signatures of wave activity in stable laminae within most $\mathrm{O}_{3}$ profiles (Thompson et al., 2007a, b).

INTEX-A/ICARTT and IONS-04 took place in summertime (early July to mid-August 2004). Boreal fires contributed to $\mathrm{O}_{3}$ pollution layers in the free troposphere (FT) over North America and beyond (e.g. Mao et al., 2006; Pfister et al., 2006; Val Martín et al., 2006). These layers were interleaved with $\mathrm{O}_{3}$ laminae associated with convection, lightning and a robust stratospheric $\mathrm{O}_{3}$ source. Over northeastern North America, tracer correlations and trajectories
(Thompson et al., 2007b) assigned a tropospheric $\mathrm{O}_{3}$ budget: stratospheric injection (25\%); boundary-layer pollution $(10 \%)$; regional convective redistribution of $\mathrm{O}_{3}$ and/or its precursors, including lightning (15\%); advected pollution and/or background $\mathrm{O}_{3}(50 \%)$. The tropospheric $\mathrm{O}_{3}$ column over northeastern North America averaged 45 DU (Dobson Units; $1 \mathrm{DU}=2.69 \times 10^{16} \mathrm{~cm}^{-2}$ ), with $\sim 22-26$ DU consisting of advected and/or background air. Values at Houston in 2004 were similar, 48 DU (total troposphere) and 28 DU (advected).

The three-phase IONS-06 (sample distribution in Table 1), addressed the broad set of transport issues posed by INTEXB/MILAGRO (http://eol/ucar.edu/milagro, Molina et al., 20081 ; http://espo.arc.nasa.gov/intex-b, Singh et al., 2008²) and TEXAQS (Texas Air Quality Study/GOMACCS (Gulf of 
Mexico Atmospheric Composition and Climate Study (http: //esrl.noaa.gov/csd/2006; Fehsenfeld et al., 2008 3 ). During MILAGRO/INTEX-B (March 2006), Phase 1 of IONS-06 coincided with aircraft sampling over Texas, Mexico and the Gulf of Mexico, to investigate export from the Mexico City Basin (MCB). Phase 2 supported INTEX-B aircraft sampling over Pacific and north-western North American inflow regions. A seasonal contrast was effected by IONS Phase-3 soundings in August and September 2006 when aircraft, ground and shipboard sampling were concentrated over Houston during the TEXAQS-06/GOMACCS.

In this paper, we quantify wave activity and tropospheric $\mathrm{O}_{3}$ budgets over the MCB and Houston urban areas, using analytical approaches similar to the IONS-04 studies (Thompson et al., 2007a, b). With a focus on $\mathrm{FT} \mathrm{O}_{3}$ in Phase 1 (early spring) and Phase 3 (late summer), the following questions are addressed:

1. How does $\mathrm{O}_{3}$ vertical structure over MCB and Houston vary day-to-day? Do we detect a similar mixture of influences (stratosphere, regional convection and lightning, advection) to those inferred in INTEX-A and IONS-04?

2. How do mean profiles and $\mathrm{O}_{3}$ budgets between spring and summer compare? Are these consistent with meteorological patterns over Houston and the MCB, where the MILAGRO period has been summarized by Fast et al. (2007)?

3. What is the role of gravity waves, a prevalent dynamical signal, in determining upper troposphere and lower stratosphere $\mathrm{O}_{3}$ over MCB and Houston?

4. How do the wave-affected laminae, tracers and trajectories translate into $\mathrm{O}_{3}$ sources? Are there links in pollution between Houston and MCB?

Over Houston, tropospheric $\mathrm{O}_{3}$ during Phase 3 of IONS-06, August-mid-September 2006, is compared with $\mathrm{O}_{3}$ profiles from the summertime IONS-04 sounding activity over Houston (Morris et al., 2006; Thompson et al., 2007a).

\section{Experimental IONS-06 observations and methods of analysis}

Ozone profiles over Houston $\left(30^{\circ} \mathrm{N}, 95^{\circ} \mathrm{W}\right)$ and $\mathrm{MCB}$ $\left(20^{\circ} \mathrm{N}, 99^{\circ} \mathrm{W}\right)$ were taken as part of IONS-06 using electrochemical concentration cell instruments coupled with standard radiosondes. The total distribution of IONS-06 sites and sample numbers appear in Table 1. The sample number designations combine the Phase 1 and 2 sondes under

\footnotetext{
${ }^{3}$ Parrish, D. D., Allen, D. T., and Bates, T. S.: Overview of the Second Texas Air Quality Study (TexAQS II) and the Gulf of Mexico Atmospheric Composition and Climate Study (GoMACCS), J. Geophys. Res., in preparation, 2008.
}

Spring; Phase 3 is referred to as Summer. For Phase 3 analyses of $\mathrm{O}_{3}$ over Houston, profiles are used from the University of Houston launch site (August 2006) and the R/V Ronald H Brown oceanographic ship (September 2006). Most launches took place in early afternoon local time. Vertical resolution is effectively $50-100 \mathrm{~m}$ (Smit et al., 2007), sufficient to detect stable layers of locally elevated (or suppressed) $\mathrm{O}_{3}$. Images of all IONS $\mathrm{O}_{3}$ profiles are at: http: //croc.gsfc.nasa.gov/intexb/ions06.html (hereafter referred to as the IONS-06 website).

As for IONS-04 (Thompson et al., 2007a), tracers for $\mathrm{O}_{3}$ origins include:

1. radiosonde PTU profiles;

2. Ertel's potential vorticity (pv; $1 \mathrm{pvu}=10^{-6} \mathrm{~m}^{2} \mathrm{~s}-1 / \mathrm{K}$ ) computed from the Goddard Earth Observing System Assimilation Model (GEOS-version 4; Bloom et al., 2005);

3. forward and backward air-parcel trajectories for each launch location and date, calculated with the kinematic version of the GSFC trajectory model (Schoeberl and Sparling, 1995) using GEOS meteorological fields at a $1 \times 1$-degree grid.

For the MCB care is taken to use terrain following trajectories only. Additional meteorological data, satellite imagery and trajectory-based domain-filling products are taken from http://croc.gsfc.nasa.gov/intexb.

Ozone and potential temperature $(\theta)$ laminae, as described in Teitelbaum et al. (1994) and Pierce and Grant (1998) are used to identify signatures of Rossby (RW) or Gravity waves $(\mathrm{GW})$. Wave frequencies at a given altitude for spring and summer are determined from the percentage of soundings within the season that have laminae with the RW or GW designation. The RW and GW classifications are refined in the "laminar identification (LID)" method to determine tropospheric $\mathrm{O}_{3}$ budgets according to four contributions, as outlined in Thompson et al. (2007a):

1. stratospheric injection (ST, from a subset of RWidentified layers, based on $\mathrm{H}_{2} \mathrm{O}$ and pv tracers);

2. regional redistribution of convection and/or lightning (RCL, taken as equivalent to GW over the tropics and sub-tropics);

3. local $\mathrm{BL}$, based on integrating $\mathrm{O}_{3}$ from the surface to the top of the mixed layer, with the latter parameter determined from the PTU;

4. advected $\mathrm{O}_{3}(\mathrm{AD})$, the residual contribution, after (1)(3), computed in column thickness (Dobson Units), have been subtracted from total tropospheric $\mathrm{O}_{3}$. $\mathrm{AD}$ represents either recently transported or aged, background $\mathrm{O}_{3}$. 
The use of an individual, dynamically derived BL height is an update to the Thompson et al. (2007a, b) method. Over $\mathrm{MCB}$, the BL at mid-day launch averages $\sim 1.8 \mathrm{~km}$ above the surface. Fast et al. (2007) note that later in the day, under convective influence, the MCB BL may extend to $2.6 \mathrm{~km}$ above surface. Over Houston, the BL is $\sim 1 \mathrm{~km}$, the value used in Thompson et al. (2007a, b).

A chemical "ozonopause" is used for LID calculations. In Thompson et al. (2007a) it was shown that although $\mathrm{O}_{3}$ budgets and free tropospheric $\mathrm{O}_{3}$ column amounts can differ significantly, depending on whether an ozone or thermal tropopause is employed, those occurrences were $<10 \%$ in a typical set of the IONS soundings. Recently, a systematic comparison of ozonopause criteria (Dougherty, 2008) demonstrated how small differences are among five accepted methods, including the one used in the present paper. Over four summers' soundings over Houston, as well as other IONS-06 sites across North America, mean seasonal ST, $\mathrm{RCL}$ and $\mathrm{AD}$ budgets differed $<5 \%$ absolute.

\section{March 2006 (MILAGRO/INTEX-B) profiles and wave activity}

\subsection{MCB and Houston ozone and relative humidity structure}

Curtains of $\mathrm{O}_{3}$ mixing ratio in $0.25-\mathrm{km}$ averages over the MCB and Houston below $17 \mathrm{~km}(95 \mathrm{hPa})$, with the tropopause in white, appear in Fig. 2. The FT over MCB has moderate $\mathrm{O}_{3}, 50-60$ ppbv (Fig. 2a) with some clean layers, $<35 \mathrm{ppbv}$, between 5 and $13 \mathrm{~km}$. These layers originate mostly from tropical marine areas, with occasional recirculation over the nearby Caribbean (refer to trajectories at the IONS-06 website, http://croc.gsfc.nasa.gov/intexb/ions06). Marine origins are implicated by locally moist layers above $9 \mathrm{~km}$ in a number of the soundings. The FT over Houston (Fig. 2b) is sometimes as clean as over MCB but $\mathrm{O}_{3}$ mixing ratios between 6 and $11 \mathrm{~km}$ average $10 \mathrm{ppbv}$ higher over Houston than MCB (contrast Fig. $2 \mathrm{c}$ and d). Over MCB the tropopause is consistently high, averaging $15.5 \mathrm{~km}$ (Fig. 2a). The $\mathrm{O}_{3}$ structure between 13 and $16 \mathrm{~km}$ describes a subtropical tropopause transition layer with $\mathrm{O}_{3}$ mixing ratio varying between 90 and 130 ppbv. More than half the March MCB and Houston profiles display a double ozonopause (see individual profiles at the IONS-06 website). For example, although Fig. 1 places a thermal tropopause at $15 \mathrm{~km}$, Fig. 3a, for 11 March 2006, is suggestive of a double ozonopause, with the higher one at $125 \mathrm{hPa}$ and the secondary one nearly coincident with the $250 \mathrm{hPa}$ layer. On some days there are multiple laminae with stratospheric influence throughout the FT. For example, on 11 March 2006 two relatively dry layers over Houston (Fig. 3a), at 250 and $350 \mathrm{hPa}$, are distinguished by back-trajectories that pass over regions of elevated pv gradient over the Pacific (Fig. 3b). For the two days prior, the locations of several back trajectories, indicated by the "+" in Fig. 3b, pass over regions where the trajectory-mapped pv indicates stratospheric influence over several days. (In Sect. 5, it is shown that the LID method computes significant $\mathrm{ST} \mathrm{O}_{3}$ for the 9-11 March 2006 Houston profiles). The uv-DIAL $\mathrm{O}_{3}$ instrument on the NASA DC-8 noted stratospheric air to $4 \mathrm{~km}$ over Houston on its 11 March 2006 MILAGRO/INTEX-B flight (Butler et al., 2007). Sondes and trajectories were used to explore the hypothesis that MCB and Houston $\mathrm{O}_{3}$ pollution are linked (see profiles and trajectories on the IONS-06 website). Note that the sondes are somewhat limited compared to aircraft observations with multiple tracers. However, direct links between MCB and Houston are not easy to establish because comprehensive aircraft data coverage throughout the MILAGRO/ INTEX-B region is uneven. For the 11 March 2006 case noted above, there appears to be MCB influence in the Houston pollution $\mathrm{O}_{3}$ layer at $750 \mathrm{hPa}$ (corresponding trajectory in Fig. 3b), but origins are actually north of MCB. The NASA DC-8 flight report for 11 March 2006 sampling over Houston, the Gulf of Mexico and MCB noted a complex $\mathrm{O}_{3}$ structure and a mixture of influences in the larger region (http:// catalog.eol.ucar.edu/milagro/report/dc-8/20060311). An extended range of MCB impact was noted, based on uv-DIAL $\mathrm{O}_{3}$ and aerosols (Butler et al., 2007), as well as other tracers. In some places biomass burning was implicated. In others, clean layers throughout the FT are noted. The complexity of flows and shifts in overall meteorology during MILAGRO are discussed by Fast et al. (2007; see also Fast and Zhong, 1998, for a larger context). The IONS-06 soundings encompass two periods of northerly flow, "Norte" events, discussed by Fast et al. (2007); they ended prior to the third Norte episode. Rather than MCB air parcels heading toward Houston, during a Norte flows are in the opposite direction.

Trajectories forward from the $\mathrm{MCB} \mathrm{O}_{3}$ sounding on 16-18 March 2006, suggest MCB flows toward Houston and the northern Gulf of Mexico, but the layers were not notably polluted (see website). Forward trajectories from MCB on 17 March 2006 ( $700 \mathrm{hPa}$ level, $\mathrm{O}_{3}$ mixing ratio 50-60 ppbv, were predicted to pass over Houston 1-2 days later, but no Houston soundings were taken on 18 and 19 March 2006. The DC-8 detected moderate pollution influences from MCB near Houston and the Gulf (see http://catalog.eol.ucar.edu/milagro/report/dc-8/20060319/ report.DC-8.200603191635.mission_summary.pdf).

Mean $\mathrm{O}_{3}, T$ and relative humidity $(\mathrm{RH})$ profiles over MCB show that a moderately polluted mixed layer (to $5 \mathrm{~km}$; Fig. 2c) gives way to a cleaner layer with relatively invariant $\mathrm{O}_{3}$ up to $10 \mathrm{~km}$ (Fig. 2c). Above $10 \mathrm{~km}$, the $\mathrm{MCB} \mathrm{O}_{3}$ mean and standard deviation increase. RH increases from $7 \mathrm{~km}$ to $10.5 \mathrm{~km}$ over MCB, suggesting surface origins, ie convective outflow in the mid-troposphere. A more complex tropopause structure over Houston, relative to MCB, displays a highly structured mean $\mathrm{O}_{3}$ profile above $13 \mathrm{~km}$ (Fig. 2b,d), with a wide range of mixing ratios, $45-180$ ppbv. Consistent with 

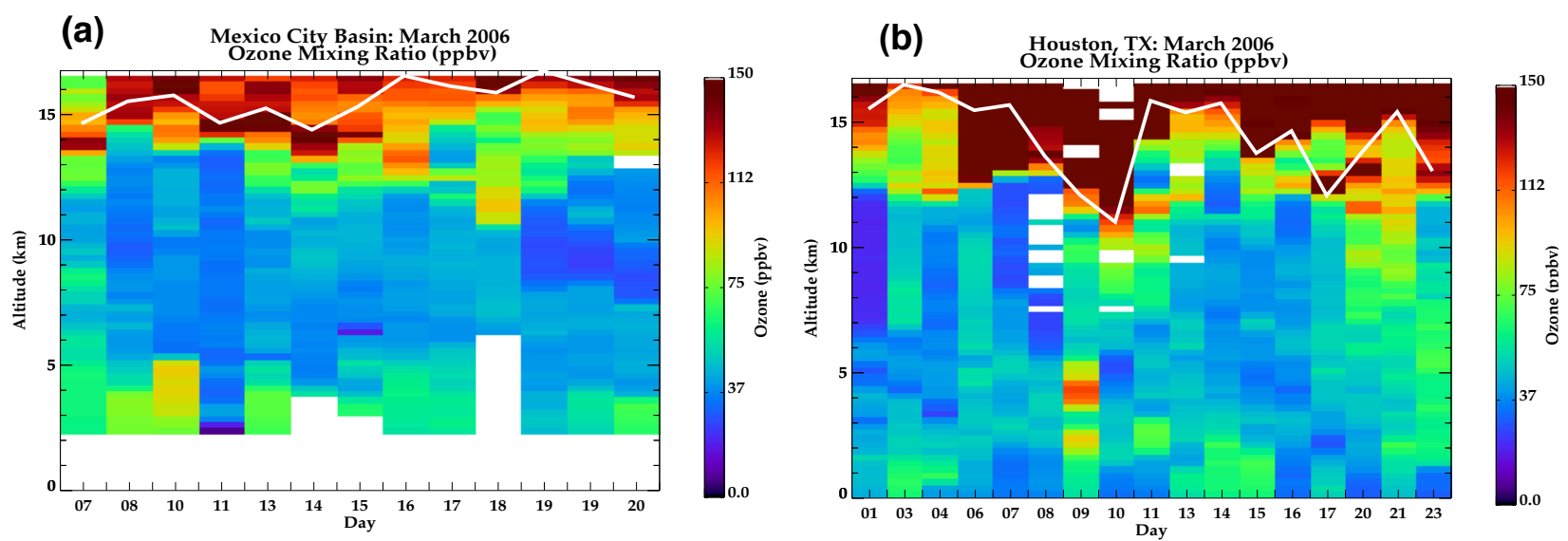

(c) Mexico City Basin: March 2006

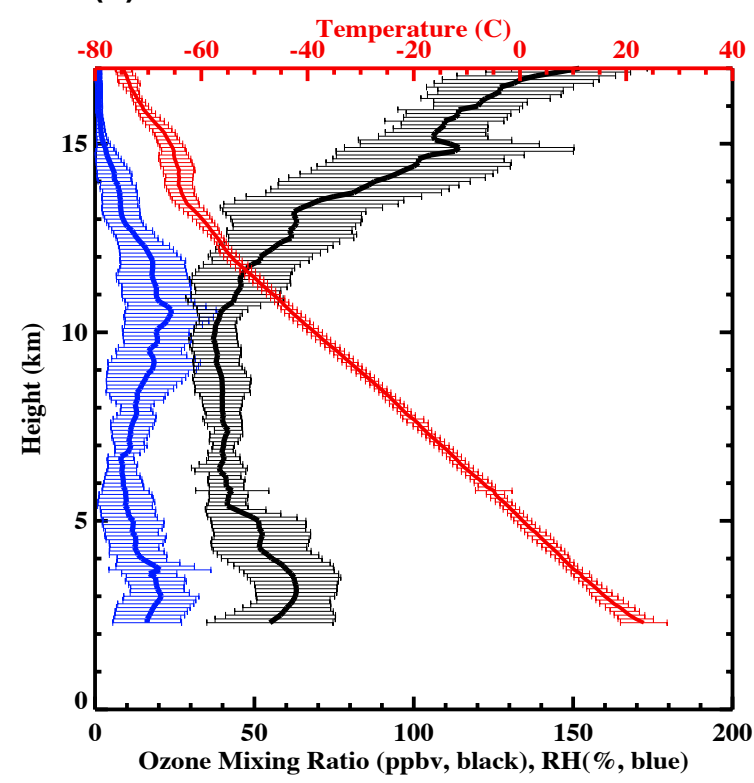

(d) Houston, TX: March 2006

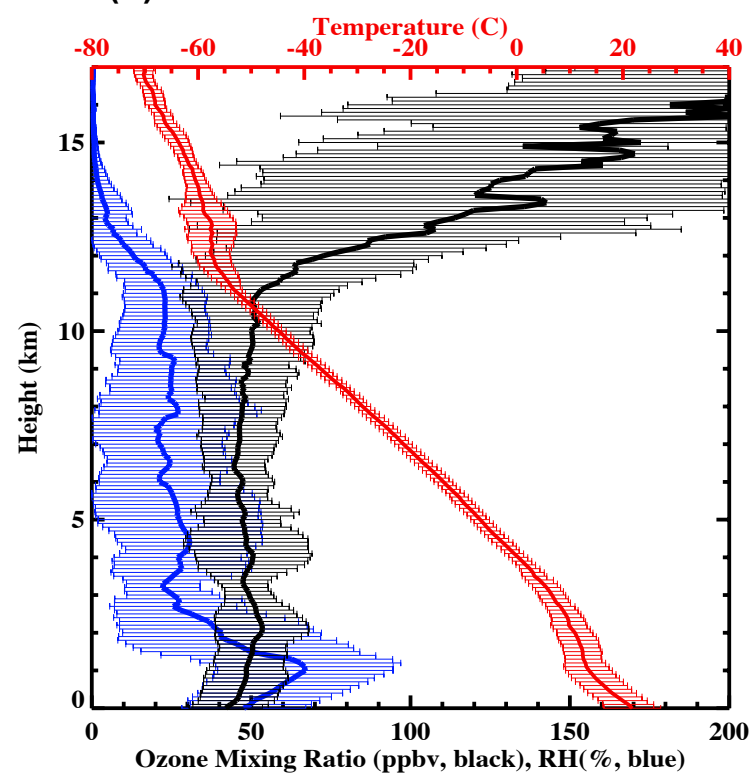

Fig. 2. Curtains of $\mathrm{O}_{3}$ mixing ratio to $17 \mathrm{~km}$ during March 2006 in the MILAGRO/INTEX-B phase of IONS-06 with the thermal tropopause indicated in white. (a) MCB from the MILAGRO T1 site at Tecámac $\left(19^{\circ} \mathrm{N}, 99^{\circ} \mathrm{W}\right)$; (b) at Houston $\left(30^{\circ} \mathrm{N}, 95^{\circ} \mathrm{W}\right)$. The interleaving of stratospheric influence, lightning, and convectively introduced $\mathrm{O}_{3}$ in the upper troposphere/lower stratosphere (UT/LS) is signified by yelloworange-red layers between $12 \mathrm{~km}$ and a sub-tropical tropopause layer (13-16 km). Mean March 2006 profiles and 1-sigma standard deviation (shaded) for temperature, $\mathrm{RH}, \mathrm{O}_{3}$ : (c) MCB and (d) Houston. Ozone and temperature profiles show a consistently located double tropopause in roughly half of the March Houston and Mexico City soundings, with complex ozone and temperature structure in the tropopause region in the remainder. As a consequence, $(\mathbf{c})$ and (d) suggest double ozonopauses where an ozone maximum and double inflection in temperature appear, at 14-15 km (MCB) and 12.5-14 km (Houston). Compare the recent study on double tropopause features in the sub-tropics (Randel et al., 2007).

the general pattern of higher $\mathrm{O}_{3}$ over Houston above $11 \mathrm{~km}$ than over MCB (also drier over Houston, suggesting stratospheric influence), the mean $T$ over Houston is greater than $T$ over MCB. It is inferred that MCB has more tropical air with a colder tropopause layer. Indeed, back trajectories from the FT over MCB are consistently from the southwest, over the Pacific, whereas those over Houston often originate from the polluted Gulf Coast or western Texas.

\subsection{Wave activity over MCB and Houston}

Stable laminae associated with wave activity, as well as thin layers of advected pollution, are standard features in $\mathrm{O}_{3}$ soundings. The morphology of wave types provides insight into processes affecting $\mathrm{O}_{3}$ soundings. Higher correlation of $\theta-\mathrm{O}_{3}$ laminae, classified as GW by Teitelbaum et al. (1994) represents vertical displacements and potential convective 


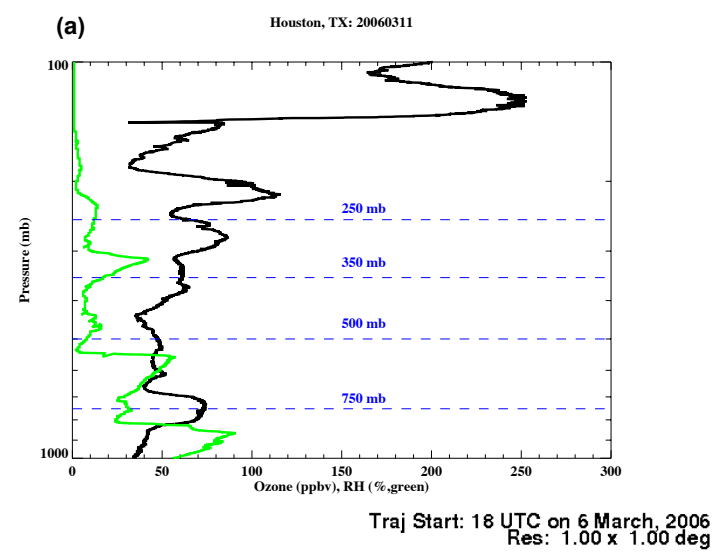

(b)

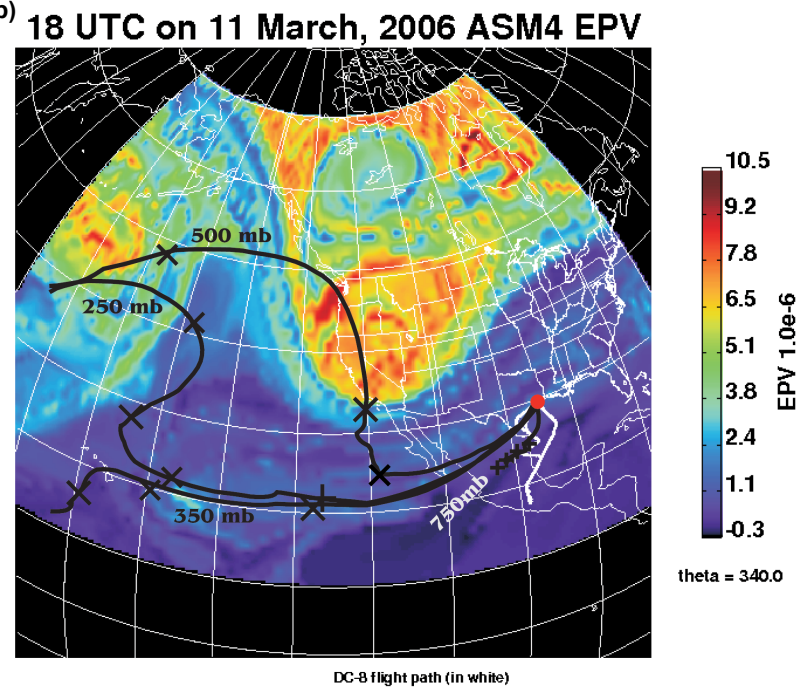

Fig. 3. (a) Profiles of $\mathrm{O}_{3}$ and $\mathrm{RH}$ over Houston on 11 March 2006 with (b) back-trajectories computed from Goddard Trajectory Model with GEOS-4 winds at indicated level, superimposed on Reverse-Domain-Fill Ertel's pv at $340 \mathrm{~K}$ surface. The 250 and $350 \mathrm{hPa}$ layers that are distinct in the $\mathrm{O}_{3}$ profile originate from regions with slightly contrasting stratospheric influence.

activity. An RW designation indicates horizontal displacements, i.e. flow along isentropes, introducing stratospheric air into the troposphere. Figure 4 displays the frequency of GW and RW activity during March 2006 over the MCB and Houston. Combined GW and RW activity is most effective above $8 \mathrm{~km}$ for Houston (black lines), giving rise to more $\mathrm{O}_{3}$ laminae and variability in the tropopause layer (Fig. 2d) than in the corresponding region over MCB (Fig. 2c). Over MCB, the increase of GW and RW in the subtropical tropopause layer is most pronounced above $12 \mathrm{~km}$. The signature of RW activity above $12 \mathrm{~km}$ for MCB (Fig. 4) is consistent with the appearance of the very dry, high- $\mathrm{O}_{3}$ layer at $\sim 160 \mathrm{hPa}$ in virtually all the March soundings (see IONS-06 website). Over the MCB there is also a high GW frequency at 3-4 km, presumably where dry convection mixes BL and lower FT air. This is where Fast et al. (2007) place the top of the convec-

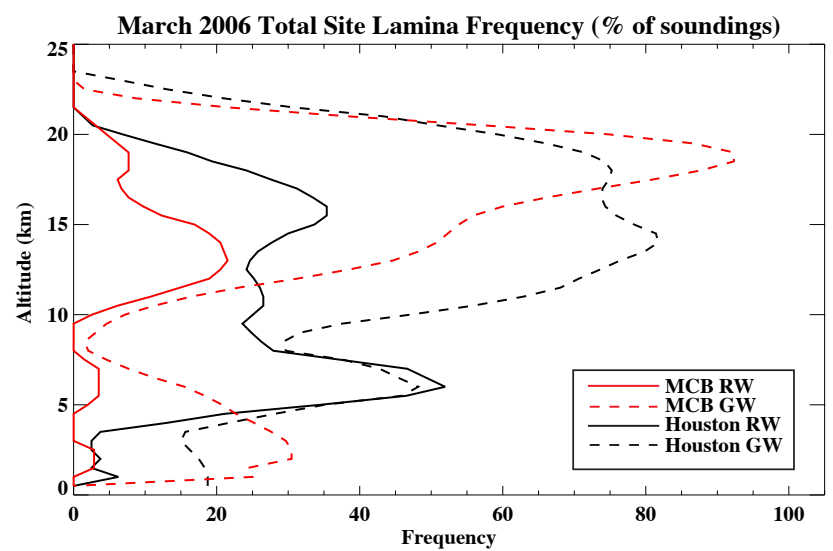

Fig. 4. Frequency of occurrence of laminae for GW (dashed) and RW (solid) over the MCB (red) and Houston (black) for the March 2006 IONS Phase 1 MILAGRO/INTEX-B period.

tive $\mathrm{BL}$. Note two $\mathrm{O}_{3}$ maxima over the $\mathrm{MCB}$ at 3.5 and $5 \mathrm{~km}$ (Fig. 2c), corresponding to the location of the GW feature (Fig. 4) and to the green shading, 50-60 ppbv, in the mixing ratio curtain (Fig. 2a).

\section{August-September 2006 ozone structure}

Figure 5a, b displays $\mathrm{MCB}$ and Houston $\mathrm{O}_{3}$ mixing ratio curtains below $17 \mathrm{~km}$ in Phase 3 of IONS-06 along with mean $\mathrm{O}_{3}, \mathrm{~T}$ and $\mathrm{RH}$ profiles (Fig. 5c, d). Below $10 \mathrm{~km}$ over the MCB (Fig. 5c), RH increases greatly in August-September, the onset of the North American monsoon, compared to spring, the late dry season. For MCB the March 2006 RH averages 10-20\% near the surface (Fig. 2c); the AugustSeptember mean exceeds $60 \%$ below $7 \mathrm{~km}$ (Fig. $5 \mathrm{c}$ ). Compared to spring, mean $\mathrm{O}_{3}$ mixing ratios at $8-12 \mathrm{~km}$ over both cities increase 20-35 ppbv. Over Houston (Fig. 5b) in August there is more yellow-orange-red above $6 \mathrm{~km}(>90 \mathrm{ppbv})$ as well as a more sharply defined tropopause (Fig. 5d), relative to spring (Fig. 2b, d). In summer, Houston $\mathrm{O}_{3}$ profiles (August-September mean is the solid line in Fig. 5d) fall into a bimodal pattern. UT $\mathrm{O}_{3}$ profiles with $>100 \mathrm{ppbv}$ features above $8 \mathrm{~km}$ are rare after 25 August 2006 (Fig. 5b). Pre- and post-25 August mean $\mathrm{O}_{3}$ profiles (depicted as dashed, 1-25 August, and dotted, 26 August-11 September, with their respective RH profiles in Fig. 5d) have little overlap to within $1-\sigma$ (not shown).

Cooper et al. (2006, 2007), compositing IONS-04 and IONS-06 profiles with MOZAIC (Measurements of Ozone by Airbus In-service Aricraft) landing/takeoff data from major airports (e.g. Dallas-Fort Worth, Atlanta), note that elevated $\mathrm{UT} \mathrm{O}_{3}$ appears to be a broad feature over summertime eastern North America. For the southern US IONS sites (Houston, Huntsville in 2004 and 2006), Cooper et al. (2006, 2007) use lightning flash data with FLEXPART to attribute 


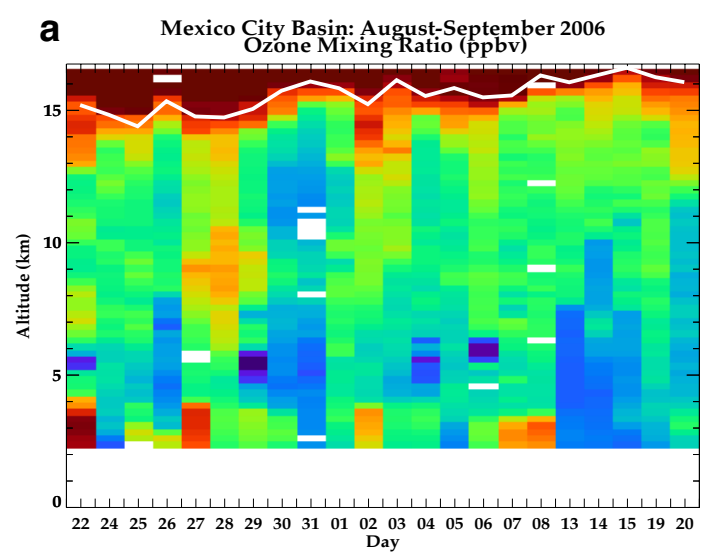

Mexico City Basin: August--September 2006

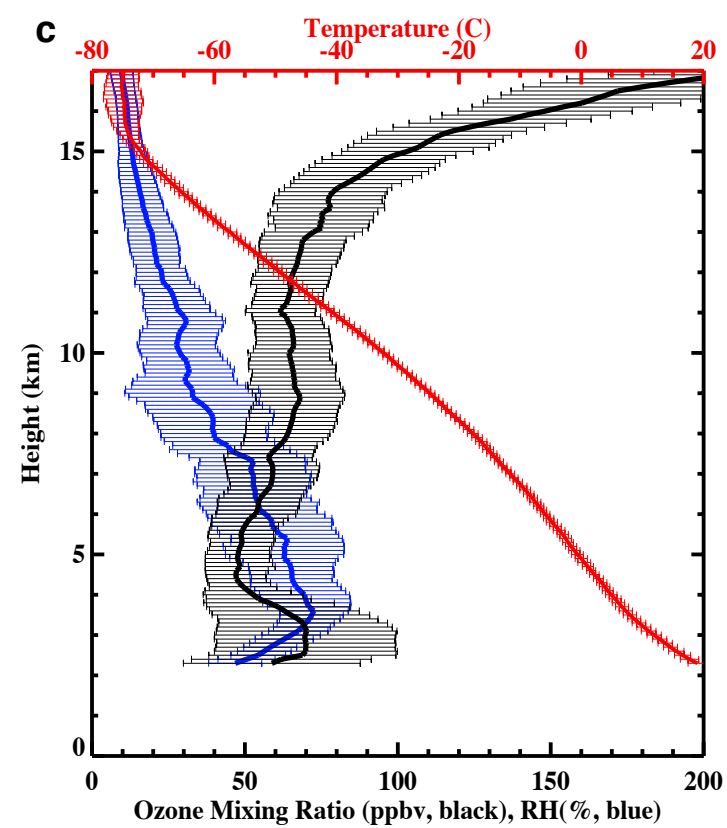

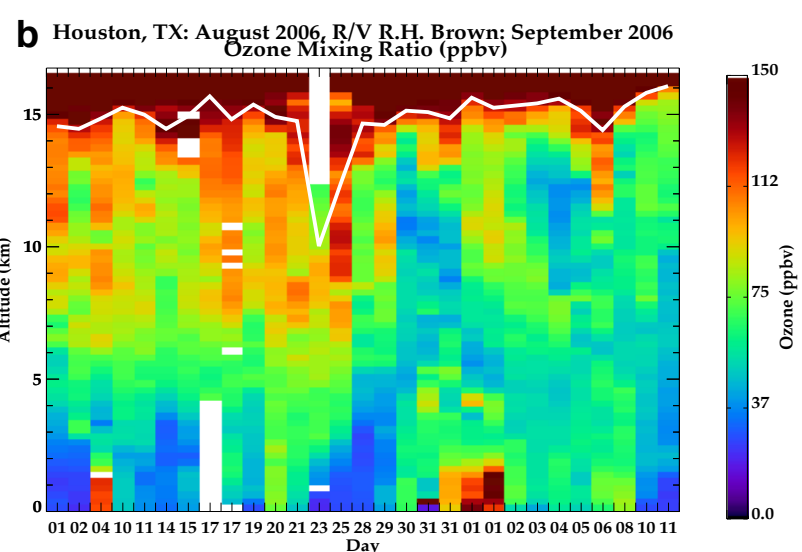

Houston, TX: August--September 2006

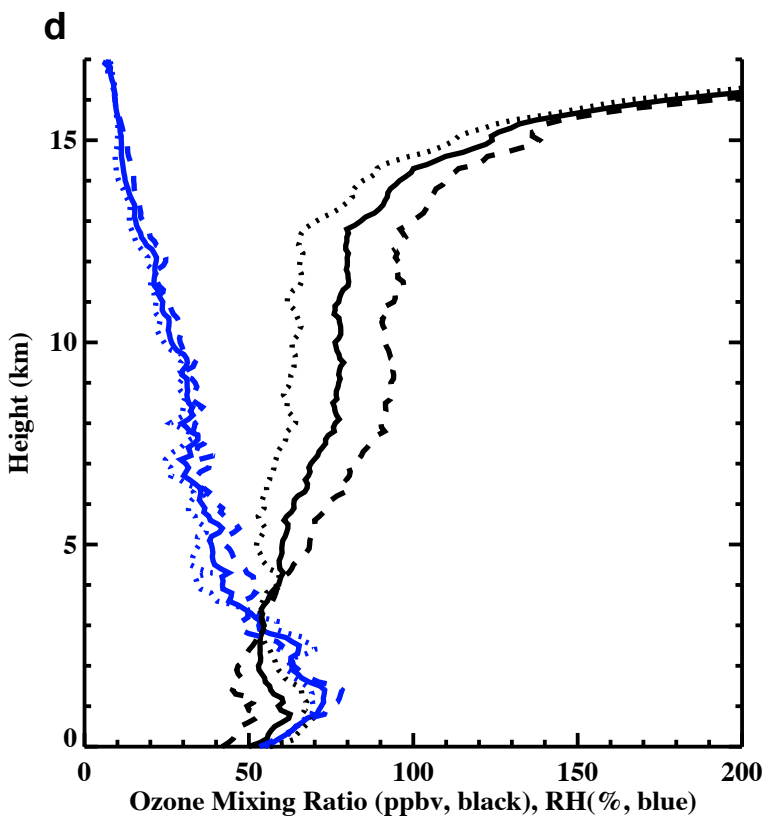

Fig. 5. (a-c) Same as Fig. 2 except for August-September 2006 sondes during Phase 3 of IONS-06. The MCB location for launching, at the Autonomous University of Mexico (UNAM) in the southern part of Mexico City, is assumed to increase BL $\mathrm{O}_{3}$ compared to the Spring T1 location with little effect in the FT. For (d) solid lines depict the August-September mean profiles over Houston. Daytime data are used with August soundings from the University of Houston launch site and September profiles based on sondes from the R/V Ronald H Brown ship Houston ship channel operations. The UT was distinct in two periods (cf. frame b), before and after 25 August, with mean profiles from the 1-25 August 2006 period (dashed) and 26 August-11 September 2006 (dotted).

most of the elevated $\mathrm{O}_{3}$ in the $10-12 \mathrm{~km}$ layer to lightning. For IONS-06, the southern US lightning interpretation (and significant $\mathrm{UT} \mathrm{O}_{3}$ from stratospheric sources over eastern North America), is further supported by analysis with a coupled chemical-transport model (Cooper et al., 2007; Hudman et al., 2007; Parrington et al., 2008).
Lightning-produced NO, along with post-convective redistribution of $\mathrm{O}_{3}$ and/or $\mathrm{O}_{3}$ precursors, has also been linked to $\mathrm{FT} \mathrm{O}_{3}$ layers over MCB in August-September 2006 (Ladino et al., 2007). This interpretation is consistent with a springto-summer RH increase above $12 \mathrm{~km}$ (deep convective outflow layers) over both cities (cf. Figs. 2c, d and 5c, d). Trajectory analysis (see IONS-06 website) shows that transport is even more decoupled between the MCB and Houston in 
Table 2. Mean $\mathrm{O}_{3}$ Budgets for Houston (IONS-06, IONS-04) and the MCB (IONS-06).

\begin{tabular}{|c|c|c|c|c|c|}
\hline $\begin{array}{l}\text { Site } \\
\text { Season }\end{array}$ & $\begin{array}{l}\text { Houston } \\
\text { Spring }\end{array}$ & $\begin{array}{l}\text { Houston } \\
\text { Summer }\end{array}$ & $\begin{array}{c}\text { Houston } \\
2004\end{array}$ & $\begin{array}{l}\text { Mexico } \\
\text { Spring }\end{array}$ & $\begin{array}{l}\text { Mexico } \\
\text { Summer }\end{array}$ \\
\hline Tropopause Height, m & 14031 & 14940 & 14689 & 15468 & 15625 \\
\hline Boundary Layer Depth, m & 1060 & 1019 & 1000 & 1826 & 1762 \\
\hline Tropospheric Column $\mathrm{O}_{3}$ (TCO, DU) & 38.0 & 45.8 & 48.6 & 27.0 & 34.0 \\
\hline Free Trop. Column $\mathrm{O}_{3}$ (FTO, DU) & 32.4 & 39.6 & 41.6 & 19.8 & 26.0 \\
\hline $\mathrm{BL} \mathrm{O}_{3}, \mathrm{DU}$ & 5.5 & 6.2 & 7.0 & 7.2 & 8.1 \\
\hline $\mathrm{BL} \mathrm{O}_{3}, \% \mathrm{TCO}$ & 14.6 & 13.4 & 14.4 & 26.7 & 23.8 \\
\hline $\mathrm{RCL} \mathrm{O}_{3}, \mathrm{DU}$ & 5.5 & 4.3 & 7.3 & 3.5 & 4.5 \\
\hline $\mathrm{RCL} \mathrm{O}_{3}, \% \mathrm{TCO}$ & 14.6 & 9.4 & 15.1 & 13.0 & 13.1 \\
\hline $\mathrm{RCL} \mathrm{O}_{3}, \%$ FTO & 17.1 & 10.9 & 17.6 & 17.7 & 17.2 \\
\hline $\mathrm{ST} \mathrm{O}_{3}, \mathrm{DU}$ & 6.6 & 6.6 & 5.9 & 2.4 & 2.4 \\
\hline $\mathrm{ST} \mathrm{O}_{3}, \% \mathrm{TCO}$ & 17.4 & 14.4 & 12.0 & 8.7 & 7.0 \\
\hline $\mathrm{ST} \mathrm{O}_{3}, \%$ FTO & 20.3 & 16.6 & 14.1 & 11.9 & 9.1 \\
\hline $\mathrm{AD} \mathrm{O}_{3}, \mathrm{DU}$ & 20.3 & 28.7 & 28.4 & 13.9 & 19.1 \\
\hline $\mathrm{AD} \mathrm{O}_{3}, \% \mathrm{TCO}$ & 53.4 & 62.8 & 58.5 & 51.6 & 56.2 \\
\hline $\mathrm{AD} \mathrm{O}_{3}, \%$ FTO & 62.5 & 72.5 & 68.3 & 70.4 & 73.7 \\
\hline
\end{tabular}

** Mexico City: Tecámac (State of Mexico) in Spring (MILAGRO T1 Site); at UNAM (Autonomous University of Mexico, Federal District) in Summer.
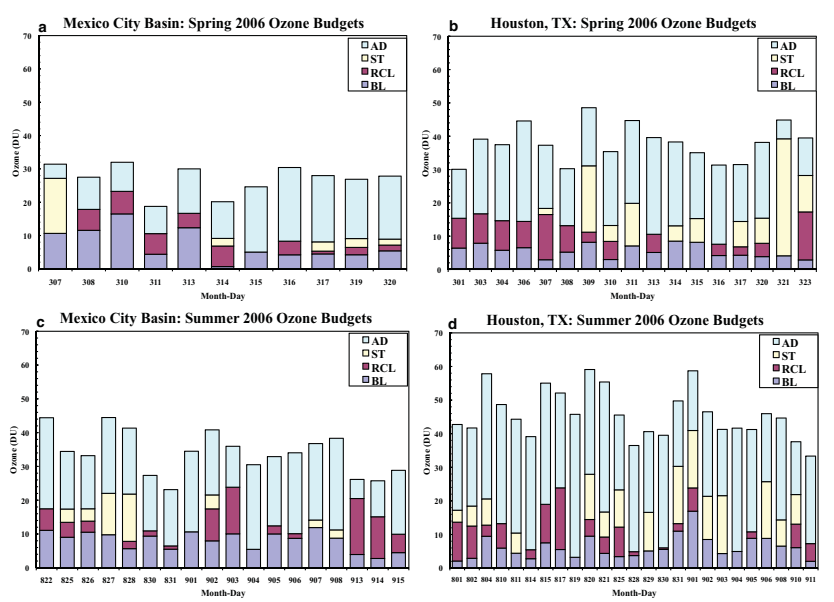

Fig. 6. Tropospheric $\mathrm{O}_{3}$ budget for the IONS-06 March 2006 soundings (a) MCB; (b) Houston. For August-September 2006: (c) MCB and (d) Houston. BL heights dynamically defined according to 2 nd derivative of the $T$ profile from the PTU sounding. Table 2 displays mean budgets.

August-September 2006 than in March 2006. Most of the air parcels from MCB head west; origins of $\mathrm{O}_{3}$ over MCB tend to be relatively localized. A few back-trajectories from Houston are from recirculation over the Gulf of Mexico; most are from the west. Flows away from Houston head north.

\section{Tropospheric wave influence and ozone budgets}

\subsection{Spring 2006}

The amount of tropospheric $\mathrm{O}_{3}$ in layers associated with $\mathrm{RW}$ and GW combined is $40 \%$ and $44 \%$ over MCB and Houston, respectively, in March 2006. Similar values hold for August-September 2006. When filtered with tracers, the corresponding $\mathrm{O}_{3}$ amounts translate to a combined ST and RCL fraction equivalent to $22 \%$ (MCB) and $32 \%$ (Houston) of the tropospheric column (Table 2). At Houston the ST fraction is twice that over MCB; convective influence (RCL in Table 2) is about the same over both cities. For the MCB the average tropospheric $\mathrm{O}_{3}$ column is $11 \mathrm{DU}$ lower than for Houston (Table 2), even though the 2-km thick BL at MCB has $1 / 3$ more $\mathrm{O}_{3}$ than the Houston BL. This appears to be due to a smaller $\mathrm{FT}_{3}$ column over MCB.

During March approximately half the $\mathrm{O}_{3}$ is designated AD (Table 2), representing a mixture of recently imported $\mathrm{O}_{3}$ pollution and a background amount of indeterminate origins, presumably mixed ST, RCL and earlier imported $\mathrm{O}_{3}$ pollution. Figure 6 depicts tropospheric $\mathrm{O}_{3}$ budgets computed by LID for daytime profiles over MCB and Houston in the March and August-September 2006 periods. In all cases there is considerable day-to-day variability in total tropospheric $\mathrm{O}_{3}$ amounts as well as in individual budget fractions. The large and variable amounts of $\mathrm{BL}_{3}$ over MCB on 5-7 March and on 13 March 2006 (Fig. 6a) are partly due to a BL height $>2 \mathrm{~km}$ above ground (not shown). Figure 6a indicates considerable $\mathrm{ST}_{3}$ over MCB on five days in March 2006. Over Houston $\mathrm{ST} \mathrm{O}_{3}$ is a consistent feature after 8 March 2006 (Fig. 6b). Individual GW fractions are 
$\sim 30 \%$ in early March 2006. After 8 March, a greater $\mathrm{ST} \mathrm{O}_{3}$ amount sets in, driven by a 20-40\% RW frequency over the remainder of MILAGRO/INTEX-B.

\subsection{Summer 2006}

Both the MCB and Houston increased in tropospheric $\mathrm{O}_{3}$ column 7-8 DU in the spring-to-summer transition (Table 2). The $\mathrm{BL} \mathrm{O}_{3}$ amounts account for only $1 \mathrm{DU}$ of the increase. Summer $\mathrm{ST}_{3}$ amounts (Table 2) did not change, although the ST fractions of total and free tropospheric $\mathrm{O}_{3}$ decline 15 $20 \%$ compared to the spring values. Stratospheric influence in the summer $\mathrm{O}_{3}$ budgets (Fig. 6c, d) is significant, appearing in 39\% of the MCB profiles and $60 \%$ of the Houston soundings.

Comparing Fig. 2,c and d with Fig. 5c, d reveals that most of the spring-to-summer $\mathrm{O}_{3}$ increases occur between 5 and $12 \mathrm{~km}$. Table 2 shows corresponding enhanced AD amounts, 5 DU over MCB and 8 DU over Houston. Recall that the AD term consists of recently imported or recirculated $\mathrm{O}_{3}$ as well as an $\mathrm{O}_{3}$ background that includes earlier ST, RCL and imported $\mathrm{O}_{3}$. Increases in relatively fresh imported or recirculated $\mathrm{O}_{3}$ and an elevated background $\mathrm{O}_{3}$ are both reasonable explanations for the higher $\mathrm{AD} \mathrm{O}_{3}$. Between the March (MILAGRO, IONS-06 Phase 1) and August-September 2006 sampling periods, RCL and ST fractions over Houston decline $\sim 30 \%$ relative to their March contributions (Table 2). This is likely to be a consequence of a highly convective spring over Houston (Fast et al., 2007). The $500 \mathrm{hPa}$ geopotential anomalies over southeastern Texas (not shown; refer to the website http://www.cdc.noaa.gov) show $>50 \mathrm{~m}$ greater-than-normal heights in March 2006. The RCL and ST $\mathrm{O}_{3}$ decreases from March to August-September 2006 over Houston are compensated for with higher $\mathrm{AD}$, from $53 \%$ of the tropospheric $\mathrm{O}_{3}$ column to $63 \%$. All four $\mathrm{O}_{3}$ component fractions change relatively little in the seasonal transition over MCB. Budget variations over Houston in August-September (Fig. 6c, d) reflect wave activity and the bimodal $\mathrm{O}_{3}$ profile comparisons (Sect. 4, Fig. 5c, d). Enhanced convection and lightning (higher $\mathrm{O}_{3}$ concentrations and $\mathrm{RH}$ above $5 \mathrm{~km}$ ) are more concentrated through $25 \mathrm{Au}-$ gust (Fig. 5d, dashed profiles), corresponding to greater $\mathrm{GW}$ activity and higher RCL fractions (Fig. 6d). Lower midtropospheric $\mathrm{O}_{3}$ mixing ratios (Fig. 5d, dotted profiles), a drier UT and a lower-altitude onset of the stratospheric $\mathrm{O}_{3}$ gradient after 25 August 2006 coincide with more $\mathrm{ST} \mathrm{O}_{3}$.

The pre- and post- 25 August 2006 contrast in $\mathrm{O}_{3}$ and $\mathrm{RH}$ Houston profiles (Fig. 5d) and in their corresponding LID budgets (Fig. 6d) is supported by meteorological analyses (Fig. 7). Prior to 25 August 2006, the fraction of RCL O (14\% of tropospheric column $\mathrm{O}_{3}$ ) was more prevalent than the ST term (9\% mean TCO fraction). The Houston region was dominated by an upper-level ridge as shown in Fig. 7a, leading to frequent convection prior to 25 August 2006; an example, with clouds on 17 August 2006, appears in Fig. 7b.

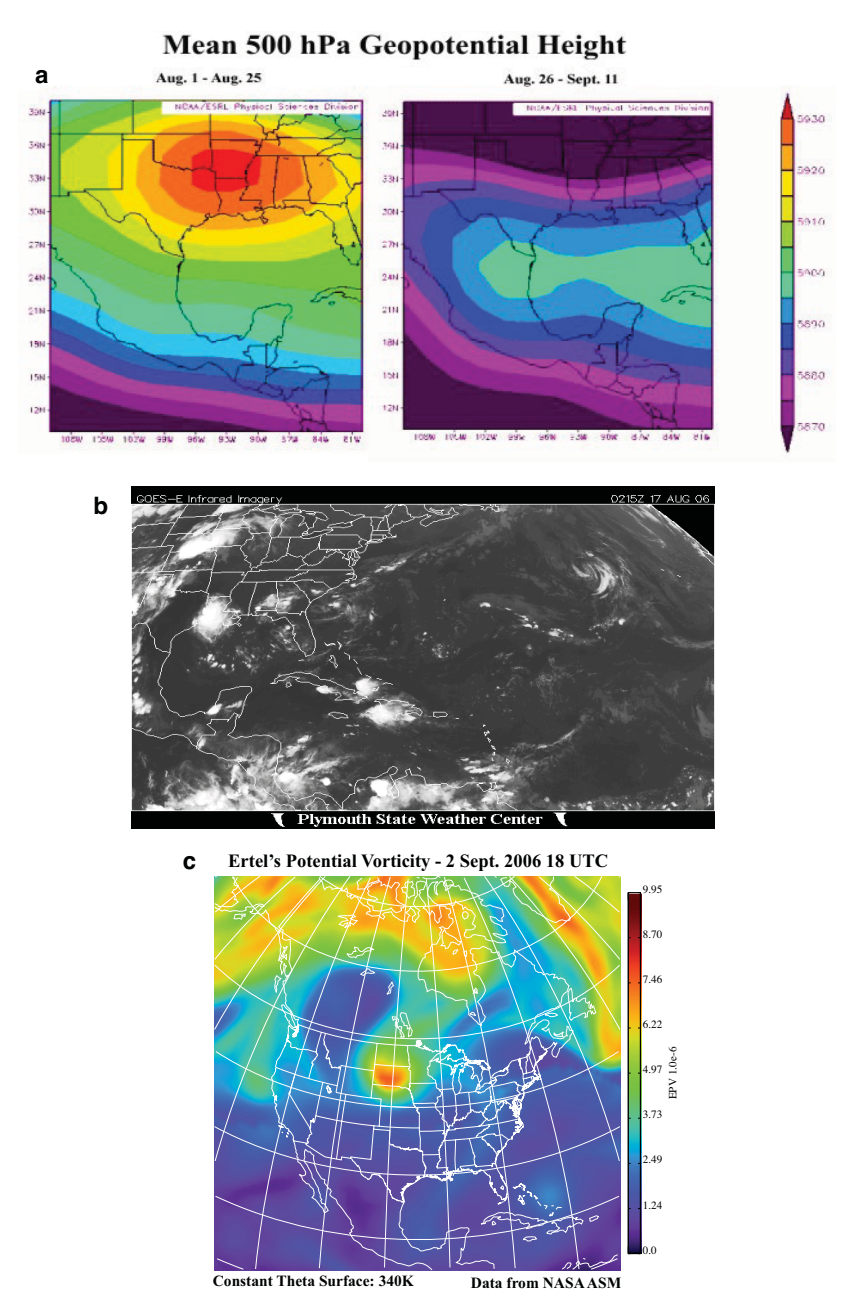

Fig. 7. (a) Mean $500 \mathrm{hPa}$ geopotential height from the NCEP/NCAR Reanalysis show an upper-level ridge dominating the southern US from 1 August to 25 August 2006 (left). Lower heights move into the region after this period (right). (Earth System Research Lab - Physical Sciences Division, http://www.cdc.noaa.gov/ Composites/Day/); (b) GOES-East infrared imagery from $17 \mathrm{Au}-$ gust 2006 at 2 UTC shows a convective system over Houston. Systems like this one were frequent from 1-25 August. (Plymouth State Weather Center, http://vortex.plymouth.edu/u-make.html); (c) Ertel's pv at $340 \mathrm{~K}$ for 2 September 2006 at 18:00 UTC using NASA's GEOS-4 Assimilation Model fields. An upper-level cut-off low over the Dakotas formed from an upper-level trough over the Pacific on 30 August 2006 and slowly moved across the US.

Lower mid-tropospheric $\mathrm{O}_{3}$ ratios, a drier UT (Fig. 6d) and a lower-altitude onset of the sharpest UT to lower stratosphere $\mathrm{O}_{3}$ gradient after 25 August 2006 coincides with more $\mathrm{ST}_{3}(20 \%)$ than $\mathrm{RCL} \mathrm{O} \mathrm{O}_{3}(5 \%)$. A cut-off upper-level trough, depicted in Fig. 7c, moved slowly across the US, likely transporting $\mathrm{O}_{3}$ from stratosphere to troposphere in early September 2006. 
Ozonesondes over Houston were launched in IONS-04 as part of INTEX-A (July-August 2004; Morris et al., 2006; Thompson et al., 2007a, b). The IONS-04 budgets differ from IONS-06 (Table 2). The ST and RCL fractions of tropospheric $\mathrm{O}_{3}$ in July-August 2004 were $\sim 25 \%$ higher than in 2006. Much of this difference is due to high RCL $\mathrm{O}_{3}$ values from 2 August to 5 August 2004 when an anomalously high $500 \mathrm{hPa}$ geopotential height and increased lightning exposure (see lightning exposure product, EL, at http: //croc.gsfc.nasa.gov/intexb) prevailed over east Texas.

\section{Summary}

Free tropospheric $\mathrm{O}_{3}$ characteristics above the Mexico City Basin and Houston during spring and summer 2006 are delineated with sondes taken in IONS-06. Laminar analysis, tracer comparisons and meteorological interpretation explain the considerable day-to-day $\mathrm{O}_{3}$ variability over both urban areas in both seasons. Wave influences are prominent in the laminar structure in the lower stratosphere and throughout the troposphere, with more frequent wave activity in spring. These signatures are consistent with vertical displacements by gravity waves (both sites) and mixing in the convective BL (Fast et al., 2007) over Mexico, where the UT/LS wave distribution resembles patterns observed over other subtropical sites (e.g. Grant et al., 1998; Loucks, 2007).

The soundings suggest that pollution transport between the Houston and Mexico City metropolitan areas during MILAGRO/INTEX-B (IONS-06 Phase 1, March 2006) was somewhat limited. This seems to agree with meteorological analyses (Fast et al., 2007) but may change with further studies of aircraft data (Molina et al., 2008 ${ }^{1}$; Singh et al., $2008^{2}$ ). Trajectory analysis, combined with the soundings, showed even less coupling in the summer (IONS-06, Phase 3, TEXAQS/GOMACCS) when both regions displayed a 7 DU increase in the tropospheric $\mathrm{O}_{3}$ column (15-20\% of the total). Most of the $\mathrm{O}_{3}$ increase was registered in enhanced advection, based on our laminar identification technique, which means a higher background amount of $\mathrm{O}_{3}$ or more likely, additional recirculation of regional pollution.

There is substantial stratospheric influence (ST) throughout the tropospheric $\mathrm{O}_{3}$ profiles, over both sites and both seasons. In spring the relatively high ST is manifest in a double tropopause feature and a subtropical tropopause layer from $13-17 \mathrm{~km}$. During summer the ST influences persisted, in $39 \%$ of the MCB soundings and $60 \%$ of those over Houston, where they were most intense after 25 August 2006. During 1-25 August 2006 over Houston, laminar analysis implicates a combination of convection/lightning and recirculating pollution in adding $20-30$ ppbv $\mathrm{O}_{3}$ to the troposphere above $8 \mathrm{~km}$ (cf. Cooper et al., 2006, 2007; Ladino et al., 2007). Moistening of the upper troposphere in early August also suggests a convective role, as does meteorological analysis.
After 25 August 2006 over Houston, convection subsides and a situation sets up that stimulates more ST influence.

The power of laminar identification to discriminate subtle but decisive impacts on $\mathrm{O}_{3}$ structure, as in IONS-04 (Thompson et al., 2007a), is confirmed in this study. Along with complementary approaches, e.g. coupled chemical-transport models, trajectory-based analyses (e.g. FLEXPART), and aircraft tracers, a coherent picture of southern North American $\mathrm{O}_{3}$ emerges. In this region, as in northeastern North America (Thompson et al., 2007b), the tropospheric $\mathrm{O}_{3}$ structure is highly variable day-to-day. Free tropospheric $\mathrm{O}_{3}$ in spring and summer 2006 is a rich mixture of ST and RCL influences. The persistence of $\mathrm{ST}_{3}$ influences in summer has also been noted in European sondes, based on trajectory and tracer analysis (Collette and Ancellet, 2005).

Acknowledgements. We are grateful to the MILAGRO project, especially to L. T. Molina, the site coordinators A. lizalde and J.-C. Arredondo at Tecámac (March 2006) and to M. de la Mora Grutter and G. Raga at UNAM (AugustSeptember 2006). Special thanks to colleagues at Tecámac: J. C. Doran, W. Shaw (DOE/PNL), T. Martin and R. Coulter (DOE/ANL). J. Fuentes (Univ Virginia), J. D. Fast (DOE/PNL), S. J. Oltmans (NOAA/GMD) and K. E. Pickering (NASA/GSFC) offered helpful comments on the manuscript. IONS was supported by NASA's INTEX project within the Tropospheric Chemistry Program (B. G. Doddridge and J. H. Crawford), with supplements at Texas from TCEQ. Thanks to J. Lelieveld (Max-Planck Institute for Air Chemistry, Mainz) and J. E. Johnson (JISAO at NOAA/Pacific Marine Environmental Lab) for the R/V R H Brown ozonesondes. All IONS-06 ozonesonde-radiosonde data and images reside at the AVDC http://avdc.gsfc.nasa.gov or INTEX archive: http://cloud1.arc.nasa.gov.

Edited by: S. Madronich

\section{References}

Bloom, S., da Silva, A., Dee, D., Bosilovich, M., Chern, J.-D., Pawson, S., Schubert, S., Sienkiewicz, M., Stajner, I., Tan, W.-W., and $\mathrm{Wu}$, M.-L.: Documentation and Validation of the Goddard Earth Observing System (GEOS) Data Assimilation System Version 4, Technical Report Series on Global Modeling and Data Assimilation 104606, 2005.

Butler, C. F., Browell, E. V., Hair, J. W., Fenn, M. A., Notari, A., Kooi, S. A., Ismail, S., Avery, M. A., and Pierce, R. B.: Observations of Ozone and Aerosols Over Mexico and Gulf of Mexico During INTEX-B/MILAGRO Field Experiment, Eos, Tran. AGU, Fall Suppl., 88, (50) Paper A33-0816, 2007.

Collette, A. and Ancellet, G.: Impact of vertical transport processes on the tropospheric ozone layering above Europe - Part 2: Climatological analysis of the past 30 years, Atmos. Environ., 39, 5423-5435, 2005.

Cooper, O. R., Stohl, A., Trainer, M., Thompson, A. M., Witte, J. C., et al.: Large upper tropospheric ozone enhancements above mid-latitude North America during summer: In situ evidence from the IONS and MOZAIC ozone measurement network, 
J. Geophys. Res., 111, D24S05, doi:10.1029/2006JD007306, 2006.

Cooper, O. R., Trainer, M., Thompson, A. M., Oltmans, S. J., et al.: Evidence for a recurring eastern North American upper tropospheric ozone maximum during summer, J. Geophys. Res., 112, D23306, doi:10.1029/2007JD008710, 2007.

Dougherty, K. M.: The effect of ozonopause placement on tropospheric ozone budgets: An analysis of ozonesonde profiles from selected IONS-06 sites, MS Thesis, The Pennsylvania State University, University Park, Pennsylvania, 2008.

Fast, J. D. and Zhong, S.: Meteorological factors associated with inhomogeneous ozone concentrations within the Mexico City basin, J. Geophys. Res., 103, 18 927-18 946, 1998.

Fast, J. D., de Foy, B., Acevedo Rosas, F., Caetano, E., Carmichael, G., Emmons, L., McKenna, D., Mena, M., Skamarock, W., Tie, X., Coulter, R. L., Barnard, J. C., Wiedinmyer, C., and Madronich, S.: A meteorological overview of the MILAGRO field campaigns, Atmos. Chem. Phys., 7, 2233-2257, 2007, http://www.atmos-chem-phys.net/7/2233/2007/.

Fehsenfeld, F. C., Ancellet, G., Bates, T. S., Goldstein, A. H., Hardesty, R. M., Honrath, R., et al.: International Consortium for Atmospheric Research on Transport and Transformation (ICARTT): North America to Europe - Overview of the 2004 summer field study, J. Geophys. Res., 111, D23S01, doi:10.1029/2006JD007829, 2006.

Grant, W. B., Pierce, R. B., Oltmans, S. J., and Browell, E. V.: Seasonal evolution of total and gravity wave induced laminae in ozonesonde data in the tropics and subtropics, Geophys. Res. Lett., 25, 1863-1866, 1998.

Hudman, R. C., Jacob, D. J., Turquety, S., Leibensperger, E. M., Murray, L. T., et al.: Surface and lightning sources of nitrogen oxides over the United States: Magnitudes, chemical evolution, and outflow, J. Geophys. Res., 112, D12S05, doi:10.1029/2006JD007912, 2007.

Huntrieser, H., Feigl, C., Schlager, H., Schröder, F., Gerbig, C., et al.: Airborne measurements of $\mathrm{NO}_{\mathrm{x}}$, tracer species, and small particles during the European Lightning Nitrogen Oxides Experiment, J. Geophys. Res., 107(D11), doi:10.1029/2000JD000209, 2002.

Jiang, Y. B., Froidevaux, L., Lambert, A., Livesey, N. J., Read, W. G., Waters, J. W., et al.: Validation of Aura Microwave Limb Sounder Ozone by ozonesonde and lidar measurements, J. Geophys. Res., 112, D24S34, doi.org/10.1029/2007JD008776, 2007.

Ladino, L., Baumgardner, D., Hernandez, A, Baumgardner, D., Grutter, M., Thompson, A. M., Long, R. B., and Yorks, J. F.: Variability in tropospheric ozone observed through ozone soundings from Mexico City, Eos, Tran. AGU, Jt. Assem. Spring Supple., 88(23), Paper A33A03, 2007.

Loucks, A. L.: Evaluation of dynamical sources of ozone laminae in the tropical troposphere and tropical tropopause layer, M.S. Thesis, The Pennsylvania State University, 2007.

Mao, H., Talbot, R. W., Troop, D., Johnson, R., Businger, S., and Thompson, A. M.: Smart Balloon Observations over the North Atlantic - Part 2: $\mathrm{O}_{3}$ Data Analysis and Modeling, J. Geophys. Res., 111, D23S56, doi:10.1029/2005JD006507, 2006.

Morris, G. A., Hersey, S., Thompson, A. M., Pawson, S., Nielsen, J. E., Colarco, P. R., et al.: Alaskan and Canadian forest fires exacerbate ozone pollution in Houston, Texas, on 19 and 20 July 2004, J. Geophys. Res., 111, D24S03,
doi:10.1029/2006JD007090, 2006.

Newell, R. N., Thouret, V., Cho, J. Y. N., Stoller, P., Marenco, A., and Smit, H. G.: Ubiquity of quasi-horizontal layers in the troposphere, Nature, 398, 316-319, 1999.

Oltmans, S. J., Johnson, B. J., Harris, J. M., Thompson, A. M., Liu, H. Y., Chan, C. Y., et al.: Tropospheric ozone over the North Pacific from ozonesonde observations, J. Geophys. Res., 109, D15S01, doi:10.1029/2003JD003466, 2004.

Parrington, M., Jones, D. B. A., Bowman, K. W., Horowitz, L. W., Thompson, A. M., Tarasick, D., and Witte, J. C.: Constraining the summertime tropospheric ozone distribution over North America through assimilation of observations from the Tropospheric Emission Spectrometer, J. Geophys. Res., doi:10.1029/2007JD009341, in press, 2007.

Pfister, G. G., Emmons, L. K., Hess, P. G., Honrath, R., et al.: Ozone production from boreal forest fire emissions, J. Geophys. Res., 111, D24S07, doi:10.1029/ 2006JD007695, 2006.

Pickering, K. E., Thompson, A. M., Scala, J. R., Tao, W.-K., Dickerson, R. R., and Simpson, J.: Free tropospheric ozone production following entrainment of urban plumes into deep convection, J. Geophys. Res., 97, 17 985-18 000, 1992.

Pierce, R. B. and Grant, W. B.: Seasonal evolution of Rossby and gravity wave induced laminae in ozonesonde data obtained from Wallops Island, Virginia, Geophys. Res. Lett., 25, 1859-1862, 1998.

Pierce, R. B., Schaack, T., Al-Saadi, J. A., Fairlie, T. D., Kittaka, C., et al.: Chemical data assimilation estimates of continental US ozone and nitrogen budgets during the Intercontinental Chemical Transport Experiment-North America, J. Geophys. Res., 112, D12S18, doi:10.1029/2006JD007722, 2007.

Randel, W. J., Seidel, D. J., and Pan, L. L.: Observational characteristics of double tropopauses, J. Geophys. Res., 112, D07309, doi:10.1029/2006JD007904, 2007.

Ridley, B. A., Dye, J. E., Walega, J. G., Zheng, J., Grahek, F. E., and Rison, W.: On the production of active nitrogen by thunderstorms over New Mexico, J. Geophys. Res., 101(D15), 20 985$21006,1996$.

Schoeberl, M. R. and Sparling, L. C.: Trajectory modeling: diagnostic tools in Atmospheric physics, S. I. F. Course CXVI, edited by: Fiocco, G. and Visconti, C., North-Holland, Amsterdam, The Netherlands, 1994.

Schoeberl, M. R., Douglass, A. R., Hilsenrath, E., Bhartia, P. K., Beer, R., Waters, J. W., Gunson, M., Froidevaux, L., Gille, J., Barnett, J., Levelt, P. F., and DeCola, P.: Overview of the EOS Aura mission, IEEE Trans., 44(5), 1066-1074, doi:10.1109/TGRS.2005.861950, 2006.

Schoeberl, M. R., Ziemke, J. R., Bojkov, B., Livesey, N., et al.: A trajectory-based estimate of the tropospheric ozone column using the residual method, J. Geophys. Res., 112, D24S49, doi:10.1029/2007JD008773, 2007.

Singh, H. B., Brune, W. H., Crawford, J. H., Jacob, D. J., and Russell, P. B.: Overview of the summer 2004 International Chemical Transport Experiment - North America (INTEX-A), J. Geophys. Res., 111, D23S02, doi:10.1029/2006JD007905, 2006.

Smit, H. G. J., Straeter, W., Johnson, B. J., Oltmans, S. J., Davies, J., et al.: Assessment of the performance of ECC-ozonesondes under quasi-flight conditions in the environmental simulation chamber: Insights from the Jülich Ozone Sonde Intercomparison Experiment (JOSIE), J. Geophys. Res., 112, D19306, 
doi:10.1029/2006JD007308, 2007.

Teitelbaum, H., Ovarlez, J., Kelder, H., and Lott, F.: Some observations of gravity-wave-induced structure in ozone and water vapour during EASOE, Geophys. Res. Lett., 21, 1483-1486, 1994.

Thompson, A. M, Stone, J. B., Witte, J. C., Miller, S. K., Pierce, R. B., et al.: Intercontinental Transport Experiment Ozonesonde Network Study (IONS, 2004): 1. Summertime Upper Troposphere/Lower Stratosphere (UT/LS) Ozone over Northeastern North America, J. Geophys. Res., 112, D12S12, doi:10.1029/2006JD007441, 2007a.
Thompson, A. M., Stone, J. B., Witte, J. C., Miller, S. K., Oltmans, S. J., Kucsera, T. L., et al.: Intercontinental Transport Experiment Ozonesonde Network Study (IONS, 2004): 2. Tropospheric Ozone Budgets and Variability over Northeastern North America, J. Geophys. Res., 112, D12S13, doi:10.1029/2006JD007670, 2007b.

Val Martín, M., Honrath, R. E., Owen, R. C., Pfister, G., Fialho, P., and Barata, R.: Significant enhancements of nitrogen oxides, black carbon and ozone in the North Atlantic lower free troposphere resulting from North American boreal wildfires, J. Geophys. Res., 111, D23S60, doi:10.1029/2006JD007530, 2006.

Zhang, L., Jacob, D. J., Bowman, K. W., Logan, J. A., Turquety, S., et al.: Ozone-CO correlations determined by the TES satellite instrument in continental outflow regions, Geophys. Res. Lett., 33, L18804, doi:10.1029/2006GL026399, 2006. 